\title{
A hangulati állapot alakulásának kockázati tényezői a perinatalis időszakban
}

\author{
Hompoth Emőke Adrienn - Töreki Annamária dr. \\ Baloghné Fúrész Veronika - Németh Gábor dr.
}

Szegedi Tudományegyetem, Általános Orvostudományi Kar, Szülészeti és Nőgyógyászai Klinika, Szeged

\begin{abstract}
Bevezetés: 2011 áprilisában bevezetésre került Szegeden a perinatalis depressziószưrés. Célkitüzés: A depresszív tünetek mértékének felderítése, illetve a perinatalis hangulati állapotváltozás kockázati tényezőinek vizsgálata. Módszer: Az Edinburgh Postnatal Depression Scale kérdőívet védőnők adtak át négy alkalommal a 3849 résztvevőnek. Eredmények: Az első trimeszterben a legmagasabb az átlagpontszám $(3,74)$, amely szignifikánsan eltér a többi mérési alkalométól. A patológiás arány is ebben az időszakban volt a legmagasabb $(10,8 \%)$. Pozitív, közepes erősségű korreláció volt a mérési alkalmak depressziópontjai között, illetve összefüggést találtunk a magasabb szűréspontszámok és az alacsonyabb születési súly között. A magasabb átlagpontszámokkal tendenciaszerü összefüggés mutatkozott az epiduralis érzéstelenítés esetén, szignifikáns pedig a nem tervezettség, a 26 év alatti vagy 34 év fölötti életkor, egyedülálló családi állapot és a multiparitás függvényében. Következtetések: Az első trimeszterben már kimutatható pszichés változások vannak, valamint összefüggés van a különböző szociodemográfiai faktorok és a pszichés mutatók között. Ennek elkerülése érdekében fontos a depressziószürés és a pszichológiai intervenció. Orv. Hetil., 2017, 158(4), 139-146.
\end{abstract}

Kulcsszavak: depressziószürés, várandósgondozás, védőnők

\section{The risk factors of mood changing during the perinatal period}

Introduction: The screening of perinatal depression was introduced in Szeged in April 2011. Aim: Our aim was to assess the extent of perinatal mood changing and to explore the risk factors of it. Method: Perinatal nurses gave the Edinburgh Postnatal Depression Scale to the 3849 participants four times. Results: In the first trimester were the highest average scores (3.74) and pathological rate (10.8\%) compared to the other measurement occasions. There was a positive correlation between the scores of the measurement occasions. The higher average scores related to the epidural anesthesia almost significantly, but significantly to the low birth weight, unplanned pregnancies, younger and older age, single marital status and multiparity of the participant. Conclusions: Even the first trimester is sensitive to pathological mood changes, which besides with other factors could be risk factors to postpartum depression. To avoid this it is important to continue the screening and provide adequate help.

Keywords: depression screening, perinatal care, perinatal nurses

Hompoth, E. A., Töreki, A., B. Fürész, V., Németh, G. [The risk factors of mood changing during the perinatal period]. Orv. Hetil., 2017, 158(4), 139-146.

(Beérkezett: 2016. augusztus 15.; elfogadva: 2016. november 15.)

\section{Rövidítések}

BDI (Beck Depression Inventory) = Beck Depresszió Kérdőív; EPDS = Edinburgh Postnatal Depression Scale; SCID = Structured Clinical Interview for DSM-IV) strukturált klinikai interjú a DSM-IV-hez
A várandósság egy jelentős mérföldkőnek tekinthető a nők életében, amikor számos változás megy végbe biológiai szinten, illetve átalakul az életritmus és a fontossági sorrend is. Ebben az időszakban pszichés tünetek jelentkezhetnek, például lehangoltság. Magyarországon még 
kevés kutatás foglalkozott ennek vizsgálatával, így a teljes lakosságra vonatkozó előfordulási arányról nincs pontos adat [1]. A Hungarostudy felmérések szerint nő a depresszív tünetekkel küzdők száma: 1988-ban a felnőtt nők 25,8\%-a panaszkodott depresszív tünetekről, 1995-ben 33,3\%-uk, ebból súlyos tünetekre 3\%, illetve 7,7\% [2]. További emelkedés figyelhető meg a súlyos depressziós tünetekkel küzdők arányában 2002 és 2006 között is, 10,7\%-ról 14,2\%-ra nőtt [3]. A külföldi szakirodalom szerint ez a tünetegyüttes a várandós nők mintegy $20 \%$ át érinti [4].

Hazai, kisebb régiót érintő kutatásokat folytattak Szeged, Békéscsaba és Szombathely térségében. A szombathelyi vizsgálat a Beck Depresszió Kérdőív (BDI) rövidített, kilenctételes változatával történt, az eredmények alapján pedig a minta 17,9\%-a jelzett depresszív tüneteket, közülük 1\%-ban voltak ezek súlyosak $[1,5]$.

A szegedi és békéscsabai kutatásokban az Edinburgh Postnatal Depression Scale (EPDS) [6] kérdőívet használták, amit Töreki és mtsai validáltak 2010-2011-ben szegedi várandós és postpartum mintán. A validálás során a SCID diagnosztikai interjú felhasználásával külön határértéket állapítottak meg az ante- és postpartum mintákon a major és kombinált depresszió felmérésére a specificitás és szenzitivitás mutatók figyelembevételével $[7,8]$. Ezeket a határértékeket alkalmazva 2010-ben a szegedi antepartum mintán 6,85\%-ban voltak minor tünetek, $3,2 \%$-ban pedig major tünetek; míg a postpartum időszakban $13,5 \%$ volt a minor és 3\% a major tüneteket mutatók aránya [9]. Szegeden és Békéscsabán 2011-ben ezek az arányok a következőképp alakultak: kóros értéket a szegedi minta $8,9 \%$-a és a békéscsabai mintal1,2\%a ért el [10].

A perinatalis depresszió kialakulásának több rizikófaktora is van, többek között a nem tervezett várandósság [11-14], a fiatalabb életkor $[1,13,15]$, illetve, ha egyedülálló vagy özvegy az illető $[11,14,15]$. Ugyanakkor a primiparitás rizikócsökkentő hatású lehet [11].

Több kutatás is vizsgálja a kezeletlen anyai depresszió hatását, összefüggéseit. Ezek eredményei szerint a depressziónak kapcsolata van a koraszüléssel [16], alacsony születési súllyal [17] és a gestatiós diabetesszel is [18]. Ezek a szövődmények az utód későbbi életére is hatással lehetnek: a koraszülés például növeli a felnőtt utódnál a depresszió [19] és a szkizofrénia [20] kialakulásának valószínúségét, az alacsony születési súly pedig a halvaszületés és a csecsemőhalálozás esélyét növeli [21], illetve felnőttkorban érrendszeri problémákhoz és 2-es típusú diabeteshez vezethet [22].

Emellett korábbi kutatások szerint az antepartum időszakban mért depresszió mértéke előre jelezheti a postpartum depresszió kialakulását [23]. Chung és mtsai [24] eredményei szerint pedig a harmadik trimeszterben mért nagyobb depressziópontszámok esetén nagyobb volt a valószínúsége, hogy a szüléskor epiduralis érzéstelenítést alkalmaztak.
A kutatás célja az volt, hogy megvizsgáljuk, a magyar mintán hogyan alakulnak a depresszió-átlagpontszámok, illetve található-e összefüggés a depresszív tünetek és a perinatalis szövődmények között. Hipotéziseink a következők voltak:

1. Pozitív kapcsolat van az antepartum és postpartum depresszív pontszámok között.

2. Összefüggés van az alacsony születési súly és a magasabb depresszív pontszámok között.

3. A harmadik trimeszterben a magasabb depressziópontszámot elérő nők nagyobb valószínűséggel igényelnek epiduralis érzéstelenítést a szüléskor.

4. Egyes demográfiai jellemzők (fiatalabb életkor, egyedülálló családi állapot és a multiparitás), valamint a várandósság nem tervezettsége szintén kapcsolatban állnak a magasabb depresszív pontszámokkal.

\section{Módszer}

\section{A minta}

A kutatásban azoknak a személyeknek az adatait használtuk fel, akik a 2011 áprilisában Szegeden elindult perinatalis depressziószürésben vettek részt. Eddig összesen 3849 kitöltő volt. Egyetlen kizáró tényezője a szűrésben való részvételnek, ha nem beszélt magyarul, emellett fiatalkorú anya részvételéhez szülői beleegyezést kértünk. A legfiatalabb személy 13 éves volt, a legidősebb 43 éves, az átlagéletkor 30,58 év volt $(S D=5,060)$. A legtöbben élettársi kapcsolatban vagy házasságban éltek (1048 és 1780 fő). A legtöbben először szülők voltak (1969 fó), 1085 személynek volt egy és 318-nak kettő gyermeke, míg a többieknek három vagy annál több. Az esetek $87,5 \%$-ában volt szó tervezett terhességről.

Az alacsony születési súly, valamint az érzéstelenítés módja és a depressziópontok kapcsolatának vizsgálatához egy almintát hoztunk létre: 1325 fó adatait gyújtöttük ki eddig a beteg-nyilvántartási rendszerből, közülük 129 személyt zártunk ki az elemzések során ikerszülés miatt, illetve, ha más klinikán szült, így az adataihoz nem volt hozzáférésünk. Az almintában az átlagéletkor 30,5 év volt $(S D=4,964)$. A legtöbben élettársi kapcsolatban vagy házasságban éltek (338 és 556 fő). A többség először szülő volt (628 fö), 351 személynek volt egy gyermeke, 98-nak kettő és 34 nőnek volt három vagy annál több gyereke. Az esetek 88,9\%-ában volt szó tervezett terhességről.

\section{Eszközök, a szürés folyamata}

A szürésben az EPDS [6] kérdőívet használtuk, amely egy rövid, három-öt perc alatt kitölthető kérdőív. Tíz kérdése az elmúlt hét hangulati állapotára vonatkozik: érzett-e lehangoltságot, szorongást, összecsaptak-e feje fölött a hullámok stb. Emellett a tizedik kérdés a szuicid gondolatokat méri fel. Mindegyik kérdésre négy lehetséges válasz van, amelyekre 0-3 pont közötti értéket lehet 
adni, így a teljes kérdőív összpontszáma 0-30 közötti lehet.

A megállapított ponthatárok a 7 és 12 pont: 7 pont felett minor, 12 pont felett major depressziót valószínüsít a kérdőív a korábbi validálási eljárásunk alapján $[7,8]$. Mindkét esetben, illetve akkor is, ha a tizedik kérdésen akár csak egy pontot is kap a kitöltő, akkor javaslatot kap a pszichológus felkeresésére, amelyről szabadon dönthet, hogy él-e a lehetőséggel. A pszichológus szupportív módszer mellett a következőket alkalmazza: tanácsadás, relaxáció, szülésre felkészítés, edukáció stb., a módszer igazodik az adott időszak nehézségeihez, trimeszterspecifikusan történik a kezelés.

A szürésben a védőnőknek kulcsfontosságú a szerepük: ők adják át a tájékoztató és beleegyező nyilatkozatot a várandósoknak az első találkozás alkalmával, ez után a demográfiai adatok felvételére kerül sor, majd pedig az EPDS kérdőív kitöltésére. A második és harmadik trimeszterben, illetve egyszer a postpartum időszakban újra megtörténik az EPDS kitöltése, így biztosítva a lehetőséget az esetleges változások követésére (1. ábra). A kérdőíveket a védőnők kiértékelik, majd eljuttatják a szürésben részt vevő pszichológushoz, aki a beteg-nyilvántartási rendszerben rögzíti az eredményeket, így a szürés Szegeden már a várandósgondozás részévé vált.

\begin{tabular}{|c|c|}
\hline $\begin{array}{c}1 . \\
\text { trimeszter }\end{array}$ & 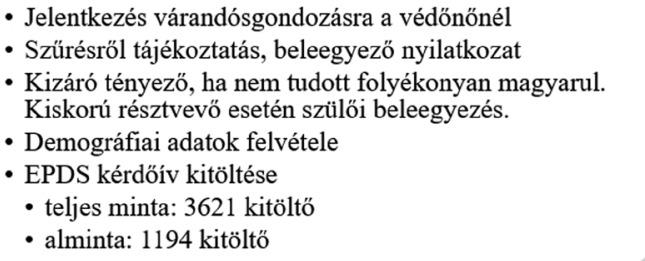 \\
\hline & $\begin{array}{l}\text { - EPDS kérdőív kitöltése } \\
\text { - teljes minta: } 2592 \text { kitöltő } \\
\text { - alminta: } 1055 \text { kitöltő }\end{array}$ \\
\hline & $\begin{array}{l}\text { - EPDS kérdőív kitöltése } \\
\text { - teljes minta: } 1593 \text { kitöltő } \\
\text { • alminta: } 858 \text { kitöltö }\end{array}$ \\
\hline & $\begin{array}{l}\text { - EPDS kérdőív kitöltése } \\
\text { • teljes minta: } 1182 \text { kitöltő } \\
\text { • alminta: } 747 \text { kitöltő } \\
\text { - Adatok gyüjtése a beteg-nyilvántartási rendszerből } \\
\text { (szülés, érzéstelenítés módja, születési hét, születési súly } \\
\text { stb.) }\end{array}$ \\
\hline
\end{tabular}

\section{Statisztika}

Mivel a mérési időszakok esetén a résztvevők száma jelentősen különbözik, így kétféle módszert alkalmaztunk annak felderítésére, hogy szignifikáns különbség van-e az EPDS-átlagpontszámokban. Egyrészt ismételt méréses
ANOVA-t használtunk, amit akkor alkalmaznak, ha ugyanazt a mérést végzik el bizonyos időközönként ugyanazon személyek részvételével. A másik módszer az egyszempontos ANOVA, amely egymástól független csoportok között elemzi az átlagpontszámok különbségét.

$\chi^{2}$-próbát is használtunk, amely alkalmas annak elemzésére, hogy a különbözó feltételek alapján létrehozott csoportok között az elemszámok különbsége a véletlennek köszönhető vagy valószínúsíthető a háttérben valamilyen hatás. Ezt a születési súly és EPDS-pontok közötti kapcsolat elemzésére használtuk, a következő csoportosítással: alacsony születési súly $(<2500 \mathrm{~g})$, illetve normális születési súly ( $\geq 2500 \mathrm{~g}$ ); emellett kontroll (akik 0-7 EPDS-pontot értek el), minor (8-12 EPDS-pont) és major csoport ( $\geq 13$ EPDS-érték). Mivel az EPDS kérdőív validálása a SCID diagnosztikai interjú alapján történt $[7,8]$, ezért megalapozottan lehet állítani, hogy a 7 pont feletti értéket elérő személyeknél minor depresszió állhat a háttérben, 12 pont felett pedig major depresszió valószínúsíthető. A besorolást a kutatási adatok feldolgozásához használjuk, nem diagnosztikus értékű.

Egyszempontos ANOVA-val elemeztük azt, hogy az EPDS-pontok alapján alakított csoportok (kontroll-, minor, major csoport) között a születési súlyok átlagában van-e szignifikáns különbség. Emellett annak felderítésére alkalmaztuk, hogy az EPDS-átlagpontszámok között van-e különbség a Lee és mtsai [15] által is alkalmazott életkor-csoportosító változó tekintetében ( $\leq 25$ éves vs. 26-34 éves vs. $\geq 35$ éves résztvevők).

$\mathrm{Az}$ ante- és postpartum depresszió kapcsolatának elemzéséhez korrelációt használtunk az EPDS-pontszámokon, mivel ez a módszer együttjárás felderítésére alkalmas, és a szakirodalom [23] szerint a postpartum depressziónak rizikófaktora (és nem oka) az antepartum depresszió, tehát a kettő közt együttjárás található.

Független mintás t-próbát is alkalmaztunk annak felderítésére, hogy van-e különbség az EPDS-pontszámokban a születési súly (alacsony vs. normál), illetve az érzéstelenítés (epiduralis érzéstelenítés vs. egyéb érzéstelenítő), mint csoportosító változók esetén. Emellett a demográfiai jellemzők, mint a várandósság tervezettsége (tervezte vs. nem tervezte), családi állapot (egyedülálló/elvált/ özvegy vs. házassági/élettársi kapcsolatban él), illetve paritás (először vs. többedszer szülő) csoportosító változók és EPDS-pontszámok közötti kapcsolat felderítésére is ezt alkalmaztuk.

\section{Eredmények}

A szürés kezdetén a várandósoknak csupán egyharmada töltötte ki a kérdőíveket, manapság már közel 90\%-os a részvételi arány. A kitöltések átlagosan a 11., 23. és 35. héten történtek, a postpartum időszakban pedig a 4-6. héten.

Ismételt méréses ANOVA-val elemeztük, hogy hogyan alakulnak az EPDS-pontszámok a mérési alkalmak 


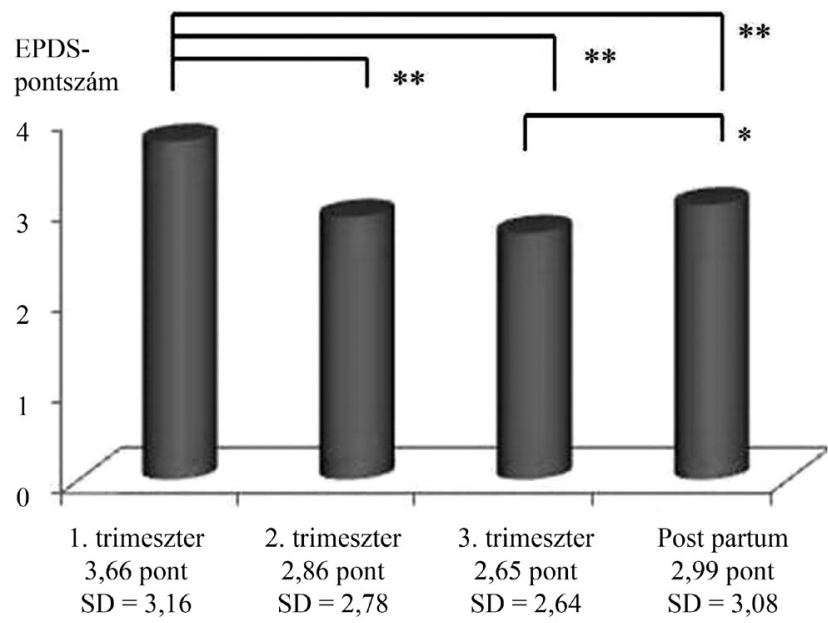

2. ábra

EPDS-átlagpontszámok a négy mérési időszakban azokon a személyeken, akik mind a négy alkalommal kitöltötték a kérdóíveket

${ }^{*} \mathrm{p}<0,001 ;{ }^{*} \mathrm{p}=0,01$

$\mathrm{SD}=$ standard deviáció

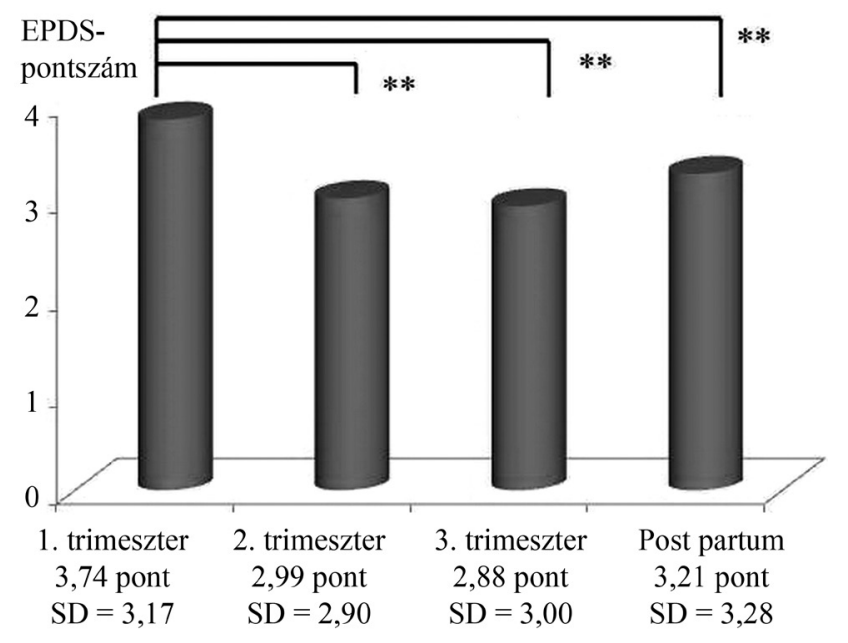

3. ábra $\mid$ A teljes minta EPDS-átlagpontszámai a négy mérési időszakban ${ }^{* *} \mathrm{p}<0,001$

$\mathrm{SD}=$ standard deviáció

során annál az 587 föt tartalmazó csoportnál, akik mind a négy alkalommal kitöltötték a kérdőívet. Eredményeink szerint a mérési alkalmak átlagpontszámai egymástól szignifikánsan eltérnek, $\mathrm{F}(2,579,1511,577)=27,832$, $\mathrm{p}<0,001$. A Bonferroni post hoc teszt szerint az első mérési alkalom átlagpontszáma a legmagasabb és mindhárom továbbitól szignifikánsan eltér $(\mathrm{p}<0,001)$, emellett szignifikáns eltérés volt a harmadik és negyedik mérési alkalom között $(\mathrm{p}=0,010)$ (2. ábra).

Az egész mintára kiterjesztve a vizsgálatot egyszempontos ANOVA-val hasonló eredményt kaptunk: a négy alkalom között szignifikáns volt az eltérés, $\mathrm{F}(3,8623)=39,093, \mathrm{p}<0,001$. A Bonferroni post hoc teszt szerint az első mérési alkalom különbözött szignifikánsan a többi háromtól $(\mathrm{p}<0,001)$ (3. ábra).

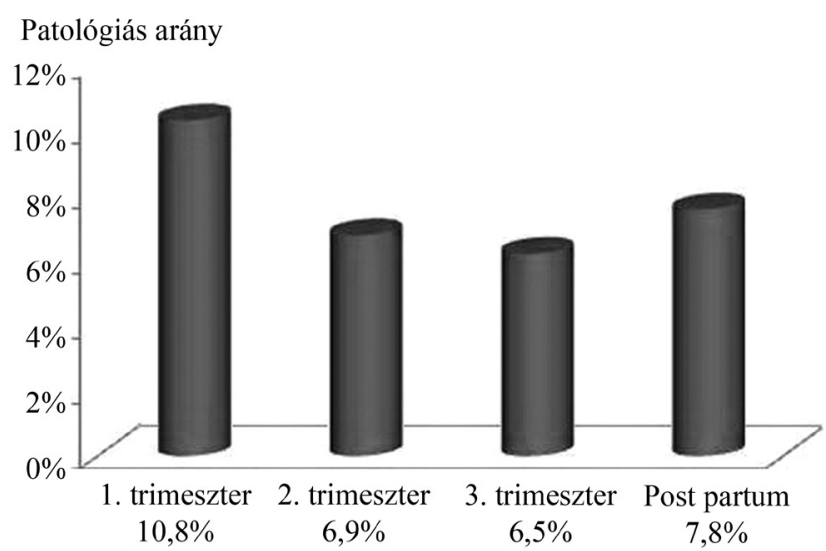

\begin{tabular}{l|l} 
4. ábra & $\begin{array}{l}\text { Patológiás EPDS-értéket elért személyek aránya a négy mérési } \\
\text { időszakban a teljes mintán }\end{array}$
\end{tabular}

A patológiás arány vizsgálatához annak a 731 kitöltésnek a pontszámait vettük figyelembe, ahol az érték hétnél nagyobb volt, ez az összes kitöltés 8,5\%-a. Az első trimeszter kitöltőinek 10,8\%-a, a második trimeszter $6,9 \%$-a, a harmadik trimeszter $6,5 \%$-a, a postpartum időszakban pedig $7,8 \%$-a volt patológiás a kitöltéseknek (4. ábra).

Korrelációval vizsgáltuk az almintán a négy mérési alkalom depressziópontszámait, eredményeink szerint mind a négy egymással pozitívan, közepesen erősen, szignifikánsan összefüggött $(0,396<\mathrm{r}<0,652, \mathrm{p}<0,001)$.

Tanulmányoztuk a születési súly és az EPDS-pontok kapcsolatát $\chi^{2}$-próbával. Eredményeink szerint a harmadik trimeszterben minor csoportban (43 fö) 9,3\%-ban, major csoportban (8 fó) 12,5\%-ban lett alacsony születési súly (25 eset), míg a kontrollcsoportban csak 2,6\%ban, a különbség szignifikáns $\left(\chi^{2}(2)=8,198, \mathrm{p}=0,017\right)$.

1. táblázat $\mid$ Az alacsony és normális születési súly eloszlása a hangulati állapot szerint

\begin{tabular}{cccc}
\hline $\begin{array}{c}\text { Kontroll } \\
\text { csoport } \\
(0-7 \text { pont })\end{array}$ & $\begin{array}{c}\text { Minor } \\
\text { csoport } \\
(8-12 \text { pont })\end{array}$ & $\begin{array}{c}\text { Major } \\
\text { csoport } \\
(13-30 \text { pont })\end{array}$ & p-érték \\
\hline
\end{tabular}

\section{3. trimeszter}

Alacsony

$2,6 \%$

$9,3 \%$

$12,5 \%$

$0,017^{*}$

születési súly

(2500 g alatt)

\begin{tabular}{ccc}
$\begin{array}{c}\text { Minor } \\
\text { csoport } \\
(8-12 \text { pont })\end{array}$ & $\begin{array}{c}\text { Major csoport } \\
(13-30 \text { pont })\end{array}$ & p-érték \\
\hline
\end{tabular}

Postpartum

$0,007^{*}$

idószak

Alacsony

$14,8 \%$

$7,4 \%$

születési súly

(2500 g alatt)

Normális

$4,7 \%$

$1,8 \%$

születési súly

(2500 g vagy

a fölött)

${ }^{*} \mathrm{p}<0,05$ 


\section{EPDS-pontszám}

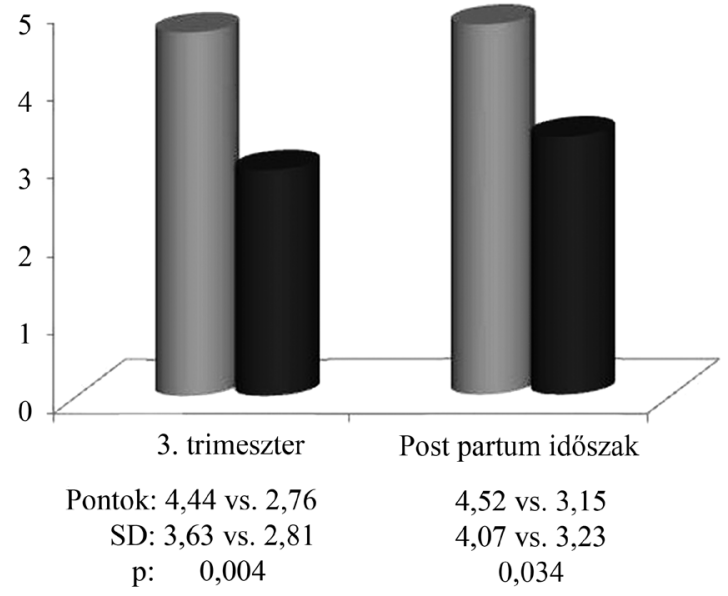

Alacsony születési súly

Normál születési súly

5. ábra

Az EPDS-pontszámok átlaga a születési súly alapján létrehozott csoportokban

$\mathrm{SD}=$ standard deviáció

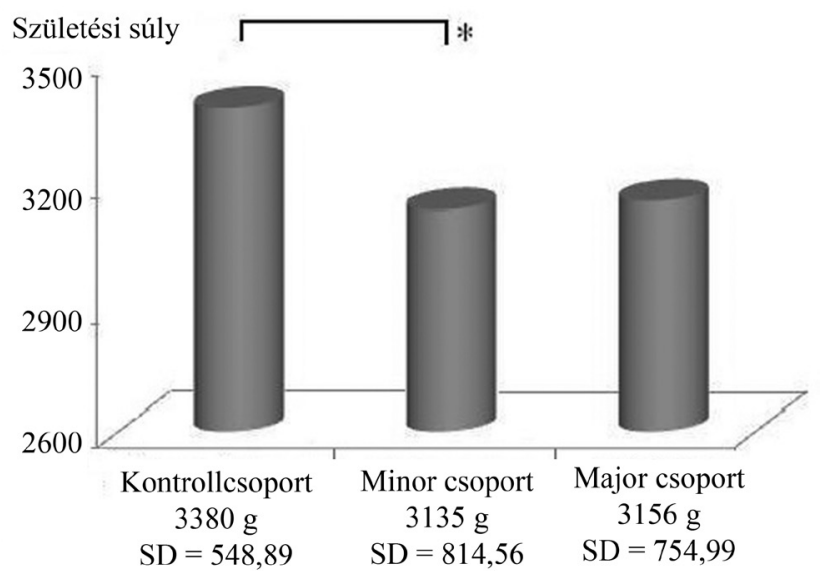

6. ábra $\quad$ A születési súlyok átlaga az EPDS-pontok alapján létrehozott csoportokban

${ }^{*} \mathrm{p}=0,016$

$\mathrm{SD}=$ standard deviáció

A postpartum időszakban pedig az alacsony születési súly csoportban (27 fó) 14,8\%-ban (4 fó) alakultak ki minor tünetek (EPDS 7-12 pont), 7,4\%-ban (2 fó) major tünetek (EPDS 13-30 pont), míg a normális születési súlyú csoportban csak 4,7\%-ban (32 személy) és 1,8\%ban (12 személy) $\left(\chi^{2}(2)=9,927, \mathrm{p}=0,007\right)$ (1. táblázat).

Független mintás t-próba szerint pedig az alacsony születési súlyú csoportban (25 és 27 fó) a normális születési súlyú csoporthoz képest szignifikánsan magasabb az EPDS-pontok átlaga a harmadik trimeszterben $(4,44$ pont, $S D=3,63$ vs. 2,76 pont, $S D=2,809)$ és a postpartum időszakban is $(4,52$ pont, $S D=4,07$ vs. 3,15 pont, $\mathrm{SD}=3,23)(\mathrm{t}(795)=2,916, \mathrm{p}=0,004$ és $\mathrm{t}(699)=2,129$, $\mathrm{p}=0,034)(5$. ábra $)$.
Az EPDS-pontok alapján kialakított csoportok (kontroll vs. minor vs. major) között a születésisúly-átlagok különbségének vizsgálatára alkalmaztuk az egyszempontos ANOVA-t. Eredményeink szerint szignifikánsan magasabb volt a kontrollcsoportban (654 fó) a születési súly (átlag $=3379,65, \mathrm{SD}=548,89$ ) a minor csoporthoz képest ( 37 fó, súly átlaga $=3134,73, \mathrm{SD}=814,56)(\mathrm{F}(2$, $702)=4,172, \mathrm{p}=0,016)$. Azonban a major csoporttól ( 14 fó, súly átlaga $=3155,71, \mathrm{SD}=754,991$ ) egyik sem tért el szignifikánsan (6. ábra).

Független mintás t-próbát használtunk az érzéstelenítés típusa (epiduralis vs. egyéb) csoportosító változó és az EPDS-átlagpontok közötti kapcsolat felderítésére. Eredményeink szerint azok a személyek, akik az epiduralis érzéstelenítést részesítették előnyben (179 fó) más módokhoz képest (1022 fó), azoknak tendenciaszerúen nagyobb volt az antepartum EPDS-pontszámuk átlaga $(3,82$ pont, $S D=2,79$ vs. 3,38 pont, $S D=2,82)$ $(\mathrm{t}(1199)=1,909, \mathrm{p}=0,056)$.

A független mintás t-próbát alkalmazva összefüggés mutatkozott az EPDS-átlagpontszámok és a várandósság tervezettsége (tervezte vs. nem tervezte) között: mind a négy mérési időszakban szignifikánsan magasabb volt az EPDS-pontok átlaga abban a csoportban, ahol nem volt tervezett a várandósság $(\mathrm{p}<0,014)$ (2. táblázat).

A családi állapot (egyedülálló/elvált/özvegy vs. élettársi/házastársi kapcsolatban él) és depressziós hangulat is szignifikánsan összefügg a független mintás t-próba szerint a második trimeszterben: akik egyedülállóak, azoknak magasabb az EPDS-átlagpontjuk azokhoz képest, akiknek van társuk, $\mathrm{t}(222)=2,280, \mathrm{p}=0,024$ (2. táblázat). Ez a tendencia jellemző az első trimeszterre és a postpartum időszakra is, bár az összefüggés nem szignifikáns.

Az életkor hatásának vizsgálatára Lee [15] kutatásához hasonlóan három csoportra bontottuk a mintát $(\leq 25$ éves vs. 26-34 éves vs. $\geq 35$ éves). Egyszempontos ANOVA szerint csak a várandósság ideje alatt van szignifikáns különbség az életkori csoportok között az EPDSátlagpontszámokban $(\mathrm{p}<0,05)$. Az első, legfiatalabb csoportban volt a legmagasabb az átlagpontszám, ezt a harmadik, legidősebb csoport követte, majd a második. A Bonferroni post hoc teszt szerint a szignifikáns eltérés mindhárom trimeszterben az első és a második, illetve a második és a harmadik csoport között volt $(\mathrm{p}<0,049)$, azonban az első és a harmadik csoport nem tért el szignifikánsan egymástól (2. táblázat).

Független mintás t-próbával vizsgálva a paritáscsoportosító változó (primipara vs. multipara) és EPDS-átlagpontok közötti kapcsolatot a következő eredményt kaptuk: mind a négy mérési alkalommal alacsonyabb volt az EPDS-átlagpontszám a primipara-csoportban a multiparákhoz képest, azonban a különbség csak a harmadik trimeszterben volt szignifikáns $(\mathrm{t}(760)=-2,106$, $\mathrm{p}=0,036)$, emellett az első trimeszterben tendenciaszerú $(\mathrm{p}=0,05 \mathrm{l})$ (2. táblázat). 


\section{Megbeszélés}

Az eredményekből összességében az látszik, hogy az első trimeszterben a legmagasabb az EPDS-átlagpontszám, amely szignifikánsan különbözik a többi átlagpontszámtól. Enyhén magasabb, de hasonlóan váltakozó átlagpontszámokat kaptak Töreki és mtsai a korábban közölt eredményeikben szegedi mintán [10]. Ugyanakkor a békéscsabai mintán nemcsak enyhén magasabbak voltak az átlagpontszámok, hanem a postpartum trimeszterben volt a legmagasabb, amelyet az első trimeszter követett. Török eredményei [14] szerint 8,12 az EPDS-átlag a szülés utáni harmadik napon, 7,93 pedig 3-9 hónap múlva, összevetve a mi mintánk 3,66 és 3,74 pontjával. Az eltéréseket okozhatja a minták közötti elemszámkülönbség, valamint, hogy a jelenlegi vizsgálatban nagyobb arányban volt tervezett a várandósság, amely protektív faktor lehet a tünetekkel szemben [11-13]. Az eltérést okozhatta továbbá a kérdőív felvételének eltérő ideje.

Kutatásunkban a patológiás értéket elért személyek aránya $8,5 \%$, ebből az első trimeszterben volt a legmagasabb, 10,8\%. Bödecs mintájában [1] a résztvevők 17,9\%-a jelzett depresszív tüneteket, Töreki és mtsai 2013-ban [9] 10\%-ban és 16,5\%-ban, 2014-ben [10] szegedi és békéscsabai mintán $8,9 \%$-ban és 11,2\%-ban talált patológiás értéket. Török [14] postpartum résztvevői közt 29,8\%-ban, szülés után 3-9 hónappal pedig 31,5\%-ban (BDI-vel) és 28,7\%-ban (EPDS-sel) álltak fent patológi- ás mértékü tünetek. A jelentősebb eltéréseket okozhatja az elemszám, a használt eszközök és a mérés időpontjának a különbözősége, valamint a demográfiai változókban való eltérés: Koppés mtsai [2] szerint a Dunántúlhoz képest a Dunától keletre jelentősen magasabb a depreszszió-átlagpontszám, Csongrád megye kivételével.

Az eredményeink érdekessége még, hogy a patológiás pontot elértek átlaga az első trimeszterben a legmagasabb. Ezt és az átlagpontszámok hasonlóan alakuló tendenciáját okozhatja az, hogy a ponthatárértéket átlépő várandósoknak jelezték a védőnők a kialakuló depresszió lehetőségét, így ők ennek tudatában kérhettek segítséget a környezetüktől, illetve szakembertől. Az is lehetséges, hogy az első trimeszter a legérzékenyebb a depresszió kialakulására, de ennek megállapításához további vizsgálatok szükségesek. Az viszont már bizonyos az eredmények alapján, hogy nemcsak a postpartum időszak érzékeny a hangulatváltozásra, hanem már az első trimeszter is, ami azért nagyon fontos, mert ha tudjuk, hogy az érzékenység már az első trimeszterben kimutatható, akkor elkezdődhet a kezelés, így elkerülhetővé válnak az esetleges későbbi szövődmények.

A statisztikai elemzés szerint, a szakirodalmi eredményekhez hasonlóan, bizonyos demográfiai jellemzők rizikófaktorai lehetnek a hangulatváltozásnak. Ilyen a nem tervezett várandósság, amely esetén eredményeink szerint mind a négy mérési időpontban szignifikánsan magasabbak voltak az EPDS-átlagpontszámok, akárcsak

2. táblázat |Az EPDS-átlagpontszámok és a demográfiai jellemzők összefüggései

\begin{tabular}{|c|c|c|c|c|c|c|c|c|c|c|c|c|}
\hline & \multicolumn{3}{|l|}{ 1. trimeszter } & \multicolumn{3}{|l|}{ 2. trimeszter } & \multicolumn{3}{|l|}{ 3. trimeszter } & \multicolumn{3}{|c|}{ Postpartum időszak } \\
\hline & Átlag & $\mathrm{N}$ & $\mathrm{p}$ & Átlag & $\mathrm{N}$ & $\mathrm{p}$ & Átlag & $\mathrm{N}$ & $\mathrm{p}$ & Átlag & $\mathrm{N}$ & $\mathrm{p}$ \\
\hline $\begin{array}{c}\text { Tervezett } \\
\text { terhesség } \\
\text { Igen } \\
\text { Nem }\end{array}$ & $\begin{array}{l}3,58 \\
(\mathrm{SD}=2,86) \\
5,45 \\
(\mathrm{SD}=3,95)\end{array}$ & $\begin{array}{l}989 \\
120\end{array}$ & 0,001 * * & $\begin{array}{l}2,84 \\
(\mathrm{SD}=2,69) \\
5,11 \\
(\mathrm{SD}=4,15)\end{array}$ & $\begin{array}{l}878 \\
103\end{array}$ & 0,001 ** & $\begin{array}{l}2,62 \\
(\mathrm{SD}=2,66) \\
4,64 \\
(\mathrm{SD}=4,03)\end{array}$ & $\begin{array}{r}720 \\
75\end{array}$ & $0,001 * *$ & $\begin{array}{l}2,96 \\
(\mathrm{SD}=2,86) \\
4,46 \\
(\mathrm{SD}=4,73)\end{array}$ & $\begin{array}{r}631 \\
67\end{array}$ & 0,013 * \\
\hline \multicolumn{13}{|l|}{ Életkor } \\
\hline$\leq 25$ év & $\begin{array}{l}4,37 \\
(\mathrm{SD}=3,24)\end{array}$ & 158 & \multirow{3}{*}{$\begin{array}{l}0,012^{*} \\
0,019^{*}\end{array}$} & $\begin{array}{l}4,08 \\
(\mathrm{SD}=3,73)\end{array}$ & 151 & \multirow{3}{*}{$\begin{array}{l}0,001 \text { * * } \\
0,048^{*}\end{array}$} & $\begin{array}{l}3,35 \\
(\mathrm{SD}=3,39)\end{array}$ & & \multirow{3}{*}{$\begin{array}{l}0,019^{*} \\
0,013^{*}\end{array}$} & $\begin{array}{l}3,44 \\
(\mathrm{SD}=3,97)\end{array}$ & 99 & \multirow{3}{*}{$0,055^{t}$} \\
\hline 26-34 év & $\begin{array}{l}3,56 \\
(\mathrm{SD}=3,12)\end{array}$ & 696 & & $\begin{array}{l}2,78 \\
(\mathrm{SD}=2,65)\end{array}$ & 641 & & $\begin{array}{l}2,56 \\
(\mathrm{SD}=2,58)\end{array}$ & 525 & & $\begin{array}{l}2,97 \\
(\mathrm{SD}=2,79)\end{array}$ & 461 & \\
\hline$\geq 35$ év & $\begin{array}{l}4,22 \\
(\mathrm{SD}=3,51)\end{array}$ & 223 & & $\begin{array}{l}3,38 \\
(\mathrm{SD}=3,22)\end{array}$ & 175 & & $\begin{array}{l}3,33 \\
(\mathrm{SD}=3,22)\end{array}$ & 141 & & $\begin{array}{l}3,71 \\
(\mathrm{SD}=3,86)\end{array}$ & 136 & \\
\hline \multicolumn{13}{|l|}{ Családi állapot } \\
\hline Egyedülálló & $\begin{array}{l}4,10 \\
(\mathrm{SD}=3,47)\end{array}$ & 192 & \multirow[t]{2}{*}{0,115} & $\begin{array}{l}3,58 \\
(\mathrm{SD}=3,39)\end{array}$ & 168 & \multirow[t]{2}{*}{0,024 * } & $\begin{array}{l}2.52 \\
(\mathrm{SD}=2,57)\end{array}$ & 142 & \multirow[t]{2}{*}{0,246} & $\begin{array}{l}3,26 \\
(\mathrm{SD}=3,61)\end{array}$ & 130 & \multirow[t]{2}{*}{0,556} \\
\hline Társsal él & $\begin{array}{l}3,7 \\
(\mathrm{SD}=3,08)\end{array}$ & 836 & & $\begin{array}{l}2,94 \\
(\mathrm{SD}=2,86)\end{array}$ & 759 & & $\begin{array}{l}2,82 \\
(\mathrm{SD}=2,84)\end{array}$ & 614 & & $\begin{array}{l}3,08 \\
(\mathrm{SD}=3,03)\end{array}$ & 538 & \\
\hline \multicolumn{13}{|l|}{ Paritás } \\
\hline Primipara & $\begin{array}{l}3,62 \\
(\mathrm{SD}=3,08)\end{array}$ & 587 & \multirow[t]{2}{*}{$0,051^{\mathrm{t}}$} & $\begin{array}{l}2,93 \\
(\mathrm{SD}=2,93)\end{array}$ & & \multirow[t]{2}{*}{$0,084^{\mathrm{t}}$} & $\begin{array}{l}2,61 \\
(\mathrm{SD}=2,74)\end{array}$ & & \multirow[t]{2}{*}{$0,036^{*}$} & $\begin{array}{l}3,11 \\
(\mathrm{SD}=3,13)\end{array}$ & 390 & \multirow[t]{2}{*}{0,845} \\
\hline Multipara & $\begin{array}{l}4,01 \\
(S D=3,25)\end{array}$ & 449 & & $\begin{array}{l}3,27 \\
(\mathrm{SD}=3,04)\end{array}$ & 395 & & $\begin{array}{l}3,05 \\
(\mathrm{SD}=2,97)\end{array}$ & 321 & & $\begin{array}{l}3,16 \\
(\mathrm{SD}=3,26)\end{array}$ & 285 & \\
\hline
\end{tabular}

${ }^{*}{ }^{*} \mathrm{p} \leq 0,001 ;{ }^{*} \mathrm{p}<0,05 ;$

ttendencia 
korábbi vizsgálatokban [11-13]. Török [14] eredménye alapján pedig a patológiás pontértékú csoportban nagyobb arányban van a nem tervezett várandósságok aránya a tervezetthez képest.

Rizikófaktor lehet a támogatás hiánya, egyedülálló családi állapot is $[11,15]$. A mi eredményeink szerint, akik egyedül éltek, azoknál a harmadik trimeszter kivételével mindhárom mérési alkalom esetén magasabb volt az EPDS-átlagpontszám, bár csak a második trimeszterben volt szignifikáns. Török szerint [14] a patológiás tüneteket mutató csoportban nagyobb arányban vannak egyedülállók a családosokhoz képest, Bödecs [1] pedig még az élettársi kapcsolathoz képest is pozitívabb hatásúnak találta a házassági kapcsolatot. Ezek a társas támogatás fontos szerepére mutatnak rá.

Eredményeink szerint a primiparitás rizikócsökkentő hatású lehet a depresszióval szemben, amelynek hátterében állhat, hogy akik többedik gyermeküket várják, ők kevésbé tudnak a várandósság élményszintű megélésére fókuszálni, hiszen már van gyerekük, akit (vagy akiket) el kell látniuk. Így elfoglaltabbak, megterhelőbb eljárniuk a szürésekre. Ha pedig a korábbi terhességben volt valamilyen komplikáció, ez külön distresszt okozhat [13]. Török [14] szerint szintén lehet az először szülésnek egyfajta protektív hatása, hiszen eredményei szerint a kóros EPDS-csoportban a legkisebb arányban a primiparák voltak.

Az életkor és EPDS-pontszámok kapcsolatának elemzésekor azt az eredményt kaptuk, hogy a fiatalabb életkor összefügg a magasabb átlagpontszámmal, hasonlóan korábbi kutatásokhoz $[1,13,15]$. Ugyanakkor a mi mintánkon a 26-34 éves korosztálynak van a legalacsonyabb átlagpontszáma, ehhez képest 34 éves kor fölött újra megemelkednek az EPDS-átlagpontszámok, míg Töreki [13] eredményei szerint a 35 év feletti időszak a legkevésbé veszélyeztetett a hangulatváltozásra. A mi eredményeink eltérését okozhatják a demográfiai tényezők, valamint a kutatásban használt eszközök eltérése. $\mathrm{Az}$ is lehetséges, hogy a korábbi vizsgálatok óta növekedtek az idősebb anyákra nehezedő terhek, amelyek sérülékenyebbé tehetik őket a depresszív tünetek kialakulására.

Eredményeink szerint emellett összefüggés van a születési súly és az EPDS-pontszámok között: a harmadik trimeszterben és a postpartum időszakban az alacsony születési súlycsoportban magasabb az EPDS-átlagpontszám, illetve nagyobb arányban fordul elő minor és major súlyosságú tünetegyüttes. Ez megerősíti Rabman eredményeit [17], ami szerint a depressziós anyáknak szignifikánsan kisebb lett az újszülöttje a nem depressziós anyákhoz képest. Illetve megerősíti Török eredményét [14] is, amely szerint az alacsony születési súly jelentős rizikófaktor a postpartum időszakban a kóros mértékú depresszív tünetek kialakulására.

Eredményeink megerősítették korábbi kutatások eredményeit $[24,25]$, miszerint az antenatalis depresszió nö- veli annak valószínưségét, hogy a szülés levezetéséhez epiduralis érzéstelenítőt kérnek a vajúdó nők. Ennek hátterében az állhat, hogy a megnövekedett fájdalomérzet - amely a depresszív állapotok velejárója [26] - enyhítéséhez erősebb fájdalomcsillapítóra van szükség [25].

Eredményeink alapján pozitív kapcsolat van az ante és postpartum depresszió között, vagyis az antepartum depresszió szintje előre jelezheti a postpartum depreszszió kialakulását Leigh és Milgrom vizsgálatához [23] hasonlóan. Ennek hátterében állhat, hogy a várandósság egy jelentős életesemény, amely komoly változásokat hozhat, újfajta stresszorokkal találkoznak a párok, még akkor is, ha már van gyermekük; ső́t egy már meglévő gyermekrôl gondoskodni fokozó tényező lehet [27]. Egyes megküzdési módok kevésbé adaptívak másokkal szemben [28], így akik csak ezeket tudják alkalmazni, azok sérülékenyebbek a depresszióval szemben, és mivel a gyermekvállalás, annak stresszfaktorai hosszú távon fennállnak, a lehangoltság tartóssá tud válni.

Figyelembe véve az eredményeket, valamint azon tapasztalatunkat, hogy a várandósok és az édesanyák nem merik felvállalni nehézségeiket, sokszor a környezetüktől sem tudnak vagy mernek segítséget kérni, megállapíthatjuk, hogy fontos a szürés, hiszen ennek segítségével a patológiás hangulatváltozásokat már a kezdeti fázisában észlelhetjük, így korábban van lehetőség a megfelelő segítség biztosítására. A korán elkezdett pszichológiai intervenció segíthet csökkenteni a depresszív tüneteket, ezzel elkerülhetővé válik a későbbiekben a major depresszió, illetve egyéb szövődmények kialakulása, mint az alacsony születési súly, így a pszichológiai intervenció hozzájárulhat a normális születési súlyhoz.

A jelenlegi vizsgálat korlátja az elemszám: a teljes mintanagyság megfelelő, azonban kevesen töltötték ki ahhoz képest mind a négyszer a kérdőívet, illetve egyes alcsoportok elemszámai jelentősen eltérnek. A jelen adatok nem mutatják külön a kezelt és kezeletlen betegek statisztikáját, ezen adatok feldolgozása folyamatban van. Emellett a jövőben tervezzük vizsgálni a depresszív pontoknak többek között a koraszüléssel, gestatiós diabetesszel, praeeclampsiával való kapcsolatát is.

Anyagi támogatás: A közlemény megírása anyagi támogatásban nem részesült.

Szerzôi munkamegosztás: H. E. A.: A kézirat megszövegezése, a hipotézisek kidolgozása, az adatok bevitele és elemzése. T. A.: A hipotézisek kidolgozása, az adatok bevitele és elemzése, a kézirat átnézése, szövegezése. B. F. V.: A vizsgálat lefolytatása. N. G.: Az elkészült kézirat szülészeti lektorálása. A kézirat végleges változatát valamennyi szerző elolvasta és jóváhagyta.

Érdekeltségek: A szerzőknek nincsenek érdekeltségeik. 


\section{Köszönetnyilvánítás}

Szeretnénk megköszönni Bodrogi Nikolettnek az adatgyúijtésben nyújtott segítségét. Emellett szeretnénk köszönetet mondani Dr. Pál Attila professzor úrnak, aki a szűrôprogram bevezetését és múködését mindvégig támogatta.

\section{Irodalom}

[1] Bödecs, T.: Negative effects and possible mechanisms of antenatal depression, anxiety and self-esteem on neonatal outcomes. $\mathrm{PhD}$ Thesis. [A várandósság alatti depresszió, szorongás és önértékelés neonatális kimenetelekre gyakorolt negatív hatásainak vizsgálata, és a lehetséges mechanizmusok feltárása. PhD-tézis.] Pécsi Tudományegyetem, Egészségtudományi Kar, 2010. Available from: http://ltsp.etk.pte.hu/portal/wp/File/Doktoriiskola/Tezisfuzetek/Ertekezes_BodecsTamas.pdf [Hungarian]

[2] Kopp, M., Szedmák, S., Löke, J., et al.: The prevalence of depressive symptoms and its relevance in the health care in the Hungarian population. [A depressziós tünetegyüttes gyakorisága és egészségügyi jelentősége a magyar lakosság körében.] Lege Artis Med., 1997, 7(3), 136-144. [Hungarian]

[3] Kopp, M., Skrabski, Á.: Men's and women's health conditions in Hungary. In: Nagy, I., Pongrácz, T. (eds.): Role changes. A report of men's and women's situation, 2009. [Nók és férfiak egészségi állapota Magyarországon. In: Nagy, I., Pongrácz, T. (szerk.): Szerepváltozások. Jelentés nők és férfiak helyzetéről. 2009.] TÁRKI és Szociális és Munkaügyi Minisztérium, Budapest, 2009, 117-136. [Hungarian]

[4] Bowen, A., Mubajarine, N.: Antenatal depression. Can. Nurse, 2006, 102(9), 26-30.

[5] Skrabski, Á., Kopp, M., Rózsa, S., et al.: Life meaning: An important correlate of health in the Hungarian population. Int. J. Behav. Med., 2005, 12(2), 78-85.

[6] Cox, J. L., Holden, J. M., Sagovsky, R.: Detection of postnatal depression. Development of the 10-item Edinburgh Postnatal Depression Scale. Br. J. Psychiatry, 1987, 150, 782-786.

[7] Töreki, A., Andó, B., Keresztúri, A., et al.: The Edinburgh Postnatal Depression Scale: Translation and antepartum validation for a Hungarian sample. Midwifery, 2013, 29(4), 308-315.

[8] Töreki, A., Andó, B., Dudas, R. B., et al.: Validation of the Edinburgh Postnatal Depression Scale as a screening tool for postpartum depression in a clinical sample in Hungary. Midwifery, 2014, 30(8), 911-918.

[9] Töreki, A., Andó, B., Kozinszky, Z., et al.: Perinatal psychopathologies at the University of Szeged, Department of Obstetrics and Gynaecology. [Perinatális pszichopatológiák a szegedi Szülészeti és Nőgyógyászati Klinikán.] Magyar Nőorvosok Lapja, 2013, 76(5), 6-12. [Hungarian]

[10] Töreki, A., Baloghné, F. V., Szenti, Z., et al.: The psychological screening process in the maternal care system. [A pszichológiai szû́rés megjelenése a várandósgondozásban.] Magyar Nőorvosok Lapja, 2014, 77(6), 12-15. [Hungarian]

[11] Dudas, R. B., Csatordai, S., Devosa, I., et al.: Obstetric and psychosocial risk factors for depressive symptoms during pregnancy. Psychiatry Res., 2012, 200(2-3), 323-328.

[12] Kozinszky, Z., Dudas, R. B., Csatordai, S., et al.: Social dynamics of postpartum depression: a population-based screening in South-Eastern Hungary. Soc. Psychiatry Psychiatr. Epidemiol. $2011,46(5), 413-423$

[13] Töreki, A.: Psychosocial risk factors and screening options for perinatal psychopathologies. PhD Thesis. Department of Ob- stetrics and Gynaecology, Albert Szent-Györgyi Medical Center, University of Szeged, Szeged, 2012. [A perinatális pszichopatológiák kialakulását elősegítő pszichoszociális faktorok és szúrési lehetőségeik. PhD-tézis.] Szegedi Tudományegyetem, SzentGyörgyi Albert Klinikai Központ, Szülészeti és Nőgyógyászati Klinika, Szeged, 2012. Available from: http://doktori.bibl. u-szeged.hu/1626/3/Toreki_Annamaria_doktori_disszert\% C3\%Alci\%C3\%B3_PDF.pdf [Hungarian]

[14] Török, Zs.: Psychiatric disorders associated with childbearing, especially the field of the maternity blues. PhD-Thesis. [Szüléshez társuló pszichiátriai zavarok, különös tekintettel a gyermekágyi lehangoltság kérdéskörére. PhD-tézis]. Humán Bölcsészettudományok Doktori Iskola, Debreceni Egyetem, Debrecen, 2009. Available from: https://dea.lib.unideb.hu/dea/bitstream/handle $/ 2437 / 81696 /$ ertekezes.pdf? sequence $=5$ \& is Allowed $=\mathrm{y}$ [Hungarian]

[15] Lee, A. M., Lam, S. K., Sze Mun Lau, S. M.., et al.: Prevalence, course, and risk factors for antenatal anxiety and depression. Obstet. Gynecol., 2007, 110(5), 1102-1112.

[16] Jesse, D. E., Seaver, W., Wallace, D. C.: Maternal psychosocial risks predict preterm birth in a group of women from Appalachia. Midwifery, 2003, 19(3), 191-202.

[17] Rahman, A., Bunn, J., Lovel, H., et al.: Association between antenatal depression and low birthweight in a developing country. Acta Psychiatr. Scand., 2007, 115(6), 481-486.

[18] Gemeay, E. M., Moawed, S. A., Mansour, E. A., et al.: The association between diabetes and depression. Saudi Med. J., 2015, 36(10), 1210-1215.

[19] Räikkönen, K., Pesonen, A. K., Kajantie, E., et al.: Length of gestation and depressive symptoms at age 60 years. Br. J. Psychiatry, 2007, 190(6), 469-474.

[20] Picchioni, M., Murray, R. M.: Schizophrenia. BMJ, 2007, 335(7610), 91-95.

[21] Chibwesha, C. J., Zanolini, A., Smid, M., et al.: Predictors and outcomes of low birth weight in Lusaka, Zambia. Int. J. Gynaecol. Obstet., 2016, 134(3), 309-314.

[22] Barker, D. J., Osmond, C., Forsén, T. J., et al.: Trajectories of growth among children who have coronary events as adults. N. Engl. J. Med., 2005, 353(17), 1802-1809.

[23] Leigh, B., Milgrom, J.: Risk factors for antenatal depression, postnatal depression and parenting stress. BMC Psychiatry, 2008, 8 , 24.

[24] Chung, T. K., Lau, T. K., Yip, A. S., et al.: Antepartum depressive symptomatology is associated with adverse obstetric and neonatal outcomes. Psychosom. Med., 2001, 63(5), 830-834.

[25] Andersson, L.: Implications of psychiatric disorders during pregnancy and the postpartum period - A population-based study. Umeå University, Sweden, Print \& Media, Umeå, 2004.

[26] Greden, J. F.: Physical symptoms of depression: unmet needs. J. Clin. Psychiatry, 2003, 64(7), 5-11.

[27] Divney, A., Gordon, D., Magriples, U., et al.: Stress and behavioral risk among young expectant couples. J. Adoles., 2016, 53, 3444.

[28] Peterson, B. D., Newton, C. R., Rosen, K. H., et al.: The relationship between coping and depression in men and women referred for in vitro fertilization. Fertil. Steril., 2006, 85(3), 802-804.

(Hompoth Emôke Adrienn,

Szeged, Semmelweis u. 1., 6725 e-mail: hompothemoke@gmail.com) 